\title{
Personal Financial Planning for College Graduates
}

\author{
Lisha Huang \\ School of Economics, Jinan University, Guangzhou, China \\ Email: 345866806@qq.com
}

Received 25 July 2016; accepted 28 August 2016; published 31 August 2016

Copyright (C) 2016 by author and Scientific Research Publishing Inc.

This work is licensed under the Creative Commons Attribution International License (CC BY). http://creativecommons.org/licenses/by/4.0/

(c) (i) Open Access

\begin{abstract}
As graduation day approaches, many college students look forward to a time when they can pursue the great things that they desire independently. But young adults, who are inadequately equipped with the essential knowledge about personal finance, make many detrimental financial mistakes until they finally become smart and diligent financial planners. If college graduates have the correct knowledge and motivation about personal finance when starting out, they can get control of their finances by making wise decisions and avoiding common pitfalls. This essay starts with determining one's personal financial goals in a realistic manner in order to set the plan. Then the essay goes on to recommend college graduates to make net worth statement in order to know the starting point of carrying out the plan. Additionally, the essay will delve into different aspects of carrying out the personal financial plan such as making a budget which serves to direct wise spending, managing credits which deals with smart borrowing, saving for the future which prepares graduates for emergencies and small extra funds and lastly, it will talk about smart investing which can bring about large wealth to college graduates who start out with little money. This essay will provide insightful information for college graduates to be financially successful.
\end{abstract}

\section{Keywords}

Personal Financial Planning, Financial Goals, Spending, Saving, Investing, College Graduates

\section{Introduction}

Financial planning is a skill most people are forced to acquire at some point in their lives because finance is a vital part in our lives. We make use of finance in a manner that almost borders on instinct, making everyday purchase decisions without much thought. Finance impacts our lives without letting us know its details. For example, central bankers and finance authorities raise or lower interest rates on savings, deposits and loans that affect us in one way or another. Sellers increase prices and wage earners ask for a raise. Schools adjust tuition 
fees. All of these involve making financial decisions and planning.

On a personal level, each of us makes individual decisions that affect us and the ones close to us. As students, we are either benefited or adversely affected by mundane decisions such as what type of student loans to apply for, whether to opt for eating in expensive restaurants or settle for eating in the school canteen, whether to pay in cash or use credit cards, whether to take a taxi or take the bus or buy a bicycle instead, or after graduation, to rent the residence or to buy an apartment using bank credits. Finance underpins every decision. It behooves us to know more about finance and financial planning.

So, as a way to achieve life success, financially planning is important to everyone, especially to college graduates who are about to live financially independently from parents for the very first time, facing historically high costs of living in most cities and limited funds to live on as a green hand in a career.

But what is usually the case is that we college graduates are often determined to achieve our dreams of a big house or a nice car, but usually have no idea of what means of getting there. And the fact is lacking knowledge about managing personal finances and poor skills in managing money can lead to detrimental living conditions, let alone realizing these great goals. As responded in a survey conducted by Ralph A. and Thomas S. (1991), some students were not interested in financial planning simply because they didn't have a complete or correct knowledge of the purpose of professional financial planning [1]. And US college students only score $62 \%$ in personal finance exams because they find financial planning guidance too vague, too detailed or not constructive enough [2]. So if introduction to financial planning can be developed according to the interests and priorities placed by students, graduates will have the correct motivation and knowledge for getting control of our finances and achieve financial security by making wise decisions from the start.

According to the survey by Ralph A. and Thomas S. (1991), students place great emphasis on those areas that provide economic security like "planning for retirement" and "an analysis of health and life insurance needs" while ranking investment vehicles which are vital for retirement planning success in the bottom half simply because they lack conception knowledge of these instruments and the time value of money. Students also rate basics of financial planning like "understanding of financial attitudes and goals", "analysis of financial resources and expenses" and "preparation of household budget" very highly [1].

With these as background, the following essay will provide insightful information that college graduates want to and need to know in order to be financially successful.

The goal of this essay is to point out the importance of financial planning for college graduates who are about to make vital financial decisions and to outline some essential aspects about personal financial planning for college graduates.

\section{Steps of Personal Financial Planning for College Graduates}

A starting point is determining one's personal financial goals in a realistic manner in order to set the plan. Thus the essay then goes on to recommend college graduates to make net worth statement in order to know the starting point of carrying out the plan. Additionally, the essay will delve into different aspects of carrying out the personal financial plan such as making a budget which serves to direct wise spending, managing credits which deals with smart borrowing, saving for the future which prepares graduates for emergencies and small extra funds and lastly, it will talk about smart investing which can bring about large wealth to college graduates who start out with little money.

Financial plans can be long or short term, structured or unstructured. Some people prefer to cross financial bridges when they come to them, while others adhere to a strict budget. There are no hard and fast rules for financial planning, since every situation and its circumstances are unique. However, there are some keys to financial success listed in Table 1.

College graduates need to bear the 6 steps above in mind in making personal financial planning in order to achieve financial success [3].

\subsection{First Step: Identifying Smart Financial Goals}

Identifying the financial goals help you determine the things you want to save and invest for, like

- a vehicle

- a tuition

- a decent living 
Table 1. Keys to financial success.

Keys to financial success
1) Identifying smart financial goals
2) Know your current financial situations
3) Spending wisely with a budget
4) Managing the credit
5) Saving for the future
6) Investing the money

- emergencies

- your individual future goals

Defining one's financial objective is vital before planning for finances. Your goals will tell you how you should manage your finances so that when you wish to meet your goals you have enough funds with you. You can then plan accordingly how much you need to save today for the future plans and how much returns you will receive on your investments to fulfill your future needs.

Your goals may be either short term, medium term or long term. Your short term goals could be, say, to pursue an MBA after a year, to purchase a two-wheeler etc. Short terms goals are defined to be met in up to three years. Medium term goals could be financing your marriage expenditure, to gift your parents a vacation package etc. These goals are defined as those needs which have to be met up to 5 years. Your long term goals could be to purchase a new house and these would have to be met after tenure of 5 years. You could further define the target date for each of these goals along with an approximate amount of funds you would require to meet these needs. And goals should be specific, measurable, attainable, realistic and time-bound, which are listed in Table 2.

Make your own list and then think about which goals are the most important to you. List your most important goals first.

Decide how many years you have to meet each specific goal, because when you save or invest you'll need to find a savings or investment option that fits your time frame for meeting each goal. Many tools exist to help you put your financial plan together. Table 3 gives an example.

\subsection{Second Step: Know Your Current Financial Situations}

A journey to financial comfort starts with taking an honest look at your entire financial situation. You'll be creating a net worth statement which clearly states what you own and what you owe. On the left side of the page, list your assets, which are what you own. And on the right side list your liabilities or debts, which are what you owe other people. See as Table 4.

Then you'll get to know your financial net worth by subtracting your liabilities from your assets. You'll have a positive net worth if your assets are larger than your liabilities. On the contrary, you'll have a negative net worth.

Your net worth statement may be updated every year to keep track of how you are doing financially. Don't feel frustrated if your net worth is negative because a reasonable financial plan can help you get into a positive position [4].

\subsection{Third Step: Spending Wisely with a Budget}

The next step is to keep track of the income and the expenses for every month, that is, to write down what we earn, and then our monthly expenses. This requires the use of a budget. A personal budget is like a roadmap for our finances. If we create a budget we'll have a better understanding of the costs that are necessary in your life and those that are nonessential. Thus a budget will help us avoid unnecessary debt and make informed financial decisions. So, the budget is an important part of our financial plan, because it will help us reach the goals we have set previously in our financial plan. A budget may also be known as a spending plan. Creating a budget can also help: 
Table 2. Objectives and approaches for financial goals.

\begin{tabular}{|c|c|c|c|}
\hline Objectives & Goals & Incorrect Approach & Right Approach \\
\hline Specific & $\begin{array}{l}\text { You need to know exactly } \\
\text { what you want and when. }\end{array}$ & $\begin{array}{l}\text { I need money to pay my college } \\
\text { fees in a year's time. }\end{array}$ & $\begin{array}{l}\text { I will save the money of RMB50,000 } \\
\text { to pay my fees at college. }\end{array}$ \\
\hline Measurable & $\begin{array}{l}\text { Your goal should be measurable } \\
\text { so that you know when you } \\
\text { can achieve it. }\end{array}$ & $\begin{array}{l}\text { I will pay off my debts } \\
\text { to my friends. }\end{array}$ & $\begin{array}{l}\text { In the next six months, I will return } \\
\text { RMB3000 to my two friends for } \\
\text { lending me their money. }\end{array}$ \\
\hline Attainable & $\begin{array}{l}\text { Your goals should be reasonable } \\
\text { i.e. within your reach. }\end{array}$ & I will save money. & $\begin{array}{l}\text { I will save RMB2000 each month by } \\
\text { cutting down on eating out and partying. }\end{array}$ \\
\hline Realistic & $\begin{array}{l}\text { Your goals need to be based on } \\
\text { resources and tasks that you can } \\
\text { reasonably accomplish. }\end{array}$ & If I save money I will be rich. & $\begin{array}{l}\text { If I save regularly, need not borrow } \\
\text { more money, I can pay off my debts } \\
\text { by next year and will have enough } \\
\text { savings till I begin to earn. }\end{array}$ \\
\hline Time-bound & $\begin{array}{l}\text { Goals with timelines allow you to track } \\
\text { your progress and encourage you to keep } \\
\text { going until you reach your goal. }\end{array}$ & $\begin{array}{l}\text { I will save money for } \\
\text { my vehicle. }\end{array}$ & $\begin{array}{l}\text { I will save RMB10,000 a year for } \\
\text { the next } 2 \text { years for my vehicle. }\end{array}$ \\
\hline
\end{tabular}

Table 3. Financial goal type, date and required action plans.

\begin{tabular}{|c|c|c|c|}
\hline Goal & Goal Type & Target Date & Action Plan Required \\
\hline Education & Short term & 2012 & Finance your fees partly from your parents' funds and partly by taking loan. \\
\hline Two-wheeler & Medium term & 2015 & $\begin{array}{l}\text { By } 2013 \text { it's expected you would begin to earn money. So you can save } \\
\text { RMB10,000 every year so in three years you can have enough funds to } \\
\text { buy a vehicle. }\end{array}$ \\
\hline Vacation & Medium term & 2018 & $\begin{array}{l}\text { Also keeping in mind this goal you can make suitable investments like } \\
\text { equity and mutual funds to earn sufficient returns to fund the vacation } \\
\text { for your parents provided you plan well in advance. }\end{array}$ \\
\hline Marriage & Long term & 2020 & $\begin{array}{l}\text { Make investments in equities, debt and mutual funds which will give } \\
\text { you sufficient returns to cover your expenses. }\end{array}$ \\
\hline House & Long term & 2022 & $\begin{array}{l}\text { You can make investments in fixed deposits which will help you to lock } \\
\text { away funds for this goal, however as this would not be enough you } \\
\text { should look at other options as well, }\end{array}$ \\
\hline
\end{tabular}

Table 4. Personal net worth statement.

\begin{tabular}{ccc}
\hline & \multicolumn{2}{c}{ Your net worth statement } \\
\hline Assets & Current Value & Liabilities \\
\hline Cash & Credit cards \\
Checking accounts & Bank loans \\
Savings & Car loans \\
Other investments & Student loans \\
Personal property & Other \\
TOTAL & TOTAL \\
\hline
\end{tabular}

- Live within our means

- Avoid unnecessary debt

- Get in the habit of saving

- Make more informed financial decisions

A budget is based on income and expenses. And the income and expenses must be divided into specific categories. This means we must create our own personal budgets to reflect what we can afford, our lifestyle, and we 
must separate our needs from your wants. Table 5 lists some specific budgeting tips.

1) Step 1: Estimate and Total the Income

Determine how much money we receive from all sources for the plan period—earnings, gifts, bonuses, interest on savings, and allowance, including:

- Employment (monthly take-home pay after taxes)

- Financial aid (after tuition, fees, books, and supplies)

- Family contributions (if any)

- Other

2) Step 2: Estimate and Total the Expenses

List all your expense. Separate them into fixed and variable expenses. Add these expenses to determine how much money you spend during each plan period.

- Fixed expenses do not change

- Car payment

- Rent

- Insurance

- Variable expenses can change

○ Utility bill

- Phone bill

○ Health care

\section{3) Step 3: Create a Funds and Expenses Worksheet}

To build a monthly funds and expenses worksheet, create a list of all your required monthly expenses, or needs, including fixed items (e.g., rent and car payments) and variable items (e.g., food and utilities). Add up the total for all monthly expenses and subtract this amount from your total monthly funds available.

Adhering to a monthly payment schedule can help you remember to pay your bills on time and plan for certain expenses ahead of time. It can also help you stick to your spending plan. You can check off each expense as it is paid. Table 6 is a funds and expenses worksheet.

4) Step 4: Analyze Your Current Income and Spending

Carefully examine the amounts you estimated for both income and expenses. Overestimating income and underestimating expenses is very easy to do and can cause big problems for your budget.

Subtract your expenses from your income for each plan period. If you come out even or need extra money, consider ways to increase your income or cut your expenses. If you have extra money, decide how you want to apply it toward your savings goal [5].

And another important thing to do is to determine different expenses. Expenses are divided into required expenses and discrepancy expenses. We should emphasize on discrepancy expenses because it can contribute to discrepancy funds. Discrepancy funds can be used for nonessentials, or "wants," like entertainment or can be put into savings each month or start investing on financial instruments. If we take good use of discrepancy funds, we can create wealth in the long run.

- Identify everything you need to spend money on in a given month, for example: Housing, Utilities, Food, Phone, Insurance, Child care, Car payment, and Health care.

- Identify everything you want to spend money on in a given month, for example: Dining out, Cable TV, Vacation, Movies, Music, Designer clothes, and MP3 player.

Table 5. Budgeting tips.
Budgeting tips
1) Estimate the income.
2) Estimate the expenses for this pay period, as well as the amount we will need
to put away for future expenses (such as car repairs or savings for a vacation).
3) Earmark money available for expenses.
4) Spend money according to your budget.
5) Regularly compare your estimated expenses to your actual spending.


- After all, we can figure out ways to increase the income and lower the expenses. The main tool is through saving and investing. We will discuss these two parts later.

Table 7 lists some ways to increase funds and reduce expenses.

\section{5) Step 5: Prepare a Trial Budget Plan}

A written plan listing your goals, your income, and your expenses reduces the temptation to overspend or spend carelessly.

Revise your plan and update it on a regular basis. We should bear in mind that a budget is a plan and a guide, not a forecast. You should expect periodically to revise advance estimates to fit reality as the reality emerges over time. Records should be kept in such a way that necessary changes or adjustments can be made easily. In

Table 6. Funds and expenses worksheet.

\begin{tabular}{|c|c|c|c|c|c|}
\hline \multicolumn{2}{|c|}{ Available Funds } & \multicolumn{2}{|c|}{ Expenses } & \multirow[t]{2}{*}{$\%$ of Funds } & \multirow[t]{2}{*}{ Due Date } \\
\hline Wages & $\$ 1000$ & Fixed & & & \\
\hline Financial aid & $\$ 500$ & Rent & $\$ 500$ & $29 \%$ & $1^{\mathrm{st}}$ \\
\hline \multirow[t]{7}{*}{ Other } & $\$ 200$ & Car payment & $\$ 150$ & $9 \%$ & $10^{\text {th }}$ \\
\hline & & Car insurance & $\$ 60$ & $4 \%$ & $12^{\text {th }}$ \\
\hline & & Variable & & & \\
\hline & & Phone & $\$ 50$ & $3 \%$ & $20^{\text {th }}$ \\
\hline & & Utilities & $\$ 150$ & $9 \%$ & $5^{\text {th }}$ \\
\hline & & Food & $\$ 300$ & $18 \%$ & $30^{\text {th }}$ \\
\hline & & Healthcare & $\$ 50$ & $3 \%$ & $20^{\text {th }}$ \\
\hline Total Income & $\$ 1700$ & Total Expenses & $\$ 1260$ & $75 \%$ & \\
\hline Discretionary Income & & & $\$ 440$ & $25 \%$ & \\
\hline
\end{tabular}

Footnote: Blank boxes are for format use and do not need to be filled.

Table 7. Ways to increase funds and reduce expenses.

Ways to increase available funds

1) Pursue a part-time job besides your full time job.

2) Pursue possible loans offered by the government to assist college graduates.

3) Invest wisely due to specific goals.

\section{Ways to reduce expenses}

1) Get a roommate to share the rent: this can greatly cut your biggest expense by half.

2) Use public transportation like buses and metro which many people can share the fee of the same journey so each individual only need to pay a little amount of money. Book tickets for long-distance trip earlier to get discounts up to at least $50 \%$ off.

3) Eat meals at home to avoid extra dinning fees and service fees.

4) Wait for items to go on sale: super markets have discounts for groceries each night and large stores carry out special offers from time to time like the taobao double-eleven festival.

5) Shop at thrift stores and online: APPs like Zhuanzhuan sell second-hand things at a price lower than $50 \%$ of the new ones. E-stores are free of high rent of physical stores so they can offer goods at a lower price.

6) Use coupons: customers are given coupons for re-buying, sharing advertisements and etc. Customers can buy at deduced prices when using coupons.

7) Save money in the first place before using it: to have money deducted directly from paychecks to social security account, deposit account, money market account etc. eliminates the possibility of spending it while earning large dividends in the long term. This will be later discussed in chapter 2.5. 
this way the budget can be an efficient instrument that gives the planner control over the financial future.

6) Step 6: Put Your Budget into Action and Keep Organized Records

Keep track of your spending and savings. A budget record book and a record of original expenditure are suggested.

7) Step 7: Evaluate the Budget Plan Periodically

Whenever your income, expenses, or goals change significantly, review your plan to see if you need to make any changes.

Significant events all have an impact on your financial plan. These may include going to post graduate school, starting a new job, moving, marrying, having children, changing jobs, divorcing, or death.

In all, the key to achieving any goal is planning-deciding how much you can afford to spend each day. Goals are easier to achieve if they are written down. They motivate us, add purpose to what we do and give a great sense of accomplishment. A financial budget plan provides an opportunity to evaluate progress and make sound decisions [6].

\subsection{Fourth Step: Managing the Credit}

If you have built a budget, taken advantage of all non-debt financial aid, and reduced expenses where possible and still find that your expenses are greater than your sources of funds, you may need to borrow. If you do have to borrow:

Borrow only as much as you need.

- Use all federal, state, and school-based loan eligibility first.

- Shop for the lowest interest rates and fees.

- Understand all terms and conditions.

- Try to make interest payments during school.

And one typical way of borrowing money is through using credit cards. Credit cards can make it possible to buy expensive things in advance. But credit cards aren't free money.

Most credit cards charge high interest rates if you fail to pay off your balance in full each month. Virtually no investment will give you the high returns to cover the high expenses charged by credit cards. That's why you're better off eliminating all credit card debt before investing and savings.

Here below are some Tips for Using Credit Cards:

\section{1) Put Away the Plastic}

Don't use a credit card unless you have enough money to pay off your credit card debts.

2) Know What You Owe

It's easy to forget how much you've spent with your credit card. Keep track of your used amount online. If you know you won't be able to pay your balance in full, try to figure out the actual amount you can pay each month and how long it'll take to pay off the balance.

- Limit yourself to one credit card.

- Understand all terms and conditions.

$\circ$ What are the monthly/annual fees?

$\circ$ What are the interest rate(s)?

3) Use a credit card only for budgeted expenses or emergencies

4) Make payments on time

5) Pay off your balance every month, if possible.

6) Pay off the Card with the Highest Rate

If you've got unpaid balances on several credit cards, you should pay as much as you can toward the card with the highest rate first, while still paying the minimum on your other cards.

Once you've paid off your credit cards, you can budget your money and begin to save and invest. And the following essay will tell you how to save and invest [7].

\subsection{Fifth Step: Saving for the Future}

A common trend among recent college graduates is to spend everything that they earn as soon as their paychecks come in. This is usually the first time that these individuals have had large amounts of steady income, making them feel wealthy and empowered to buy new things. Many use it as an opportunity to buy a new 
wardrobe, go on a nice vacation, or purchase a new car. In and of themselves, these things are all fine, but not if they cause someone to spend every last penny that they have.

Instead, college graduates should start saving because saving money is the greatest way to achieve great wealth. It is the only way that people can let their money work for them, rather than having to work for their money.

For example, if you buy a bottle of soda every day for $\$ 2.00$, that adds up to $\$ 730.00$ a year. If you saved that $\$ 730.00$ for just one year, and put it into a savings account or investment that earns $5 \%$ a year, it would grow to $\$ 931.69$ after 5 years, and grow to \$3,155.02 after 30 years. That's the power of “compounding”. With compound interest, you earn interest on the money you save and on the interest that money earns. Over time, even a small amount saved can add up to big money. Figure 1 is graph showing the power of compounding.

So we can see that if the earlier we start to save, the greater amount we can receive in the future.

Thus, waiting to save is like throwing away free money. Table 8 is a graph showing the high cost of waiting to save.

So we should realize that,

- Start saving as early as possible.

- The earlier you save, the more time your money has to grow.

- Thanks to compound interest (interest earning interest), money can grow incrementally.

- The longer you wait to save, the more money it will take to make up for lost time.

In reality, most people put enough money in a savings product to cover an emergency, like sudden unemployment. Some make sure they have up to six months of their income in savings so that they know it will absolutely be there for them when they need it [8].

Here below are some tips for saving:

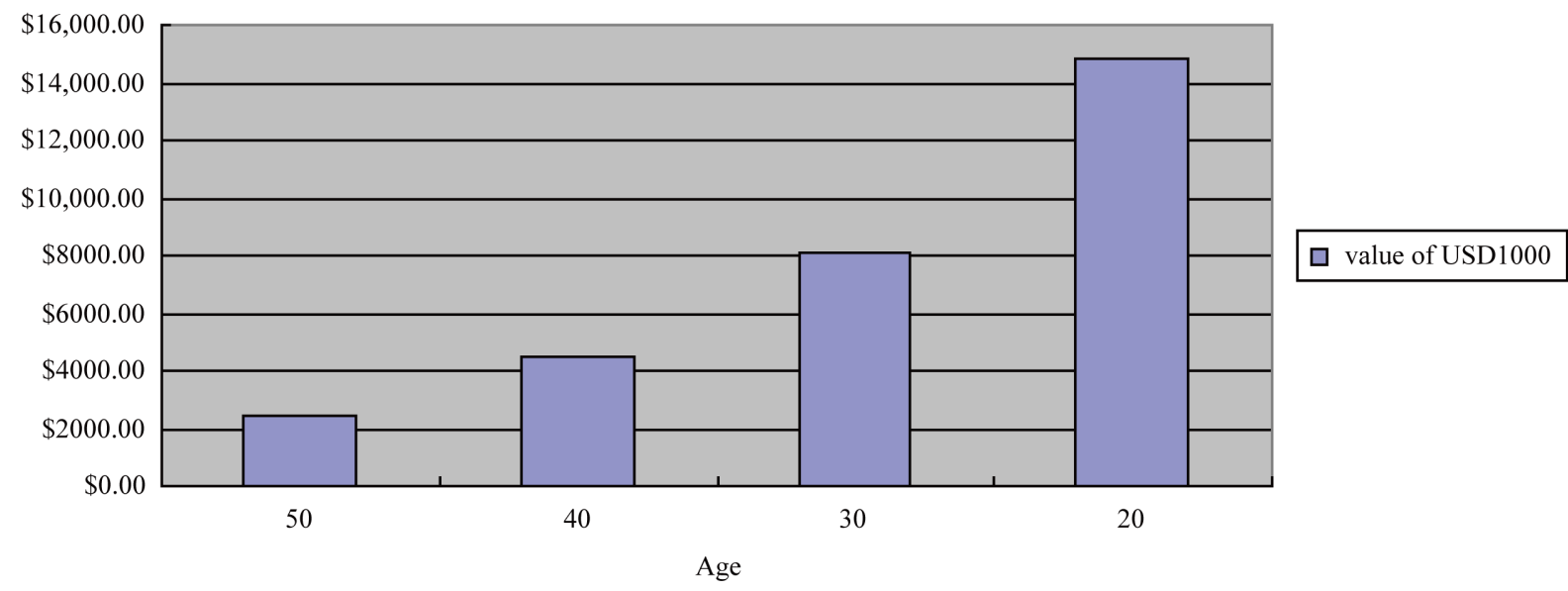

Figure 1. The value of $\$ 1000$ at the age of 65 of different age deposit starters. Footnote: annual percentage yield $=6.17 \%$.

\begin{tabular}{ccc}
\hline \multicolumn{3}{l}{ Table 8. The high cost of waiting. } \\
$\begin{array}{c}\text { If you saved } \$ 100 / \text { month } \\
\text { starting at age }\end{array}$ & $\begin{array}{c}\text { By age } 65 \text {, you } \\
\text { would have }\end{array}$ & $\begin{array}{c}\text { By waiting to save, } \\
\text { you miss out on }\end{array}$ \\
\hline 20 & $\$ 276,977$ & $\$ 0$ \\
25 & $\$ 200,145$ & $\$ 76,832$ \\
30 & $\$ 143,183$ & $\$ 133,794$ \\
35 & $\$ 100,954$ & $\$ 176,023$ \\
40 & $\$ 69,646$ & $\$ 207,331$ \\
45 & $\$ 46,435$ & $\$ 230,542$ \\
\hline
\end{tabular}

Footnote: Assumes 6\% interest, compounded monthly (APY = 6.17\%). 


\section{1) Step 1: Think Ahead}

It will be much easier for you to save money once you know what you are saving it for.

- Saving may seem impractical now (little discretionary income, unforeseen expenses)

- However, it is much easier when you establish specific goals.

- Consider your future plans after graduation - Vacation, new car, home down payment, retirement, computer, wedding

2) Step 2: Plan Ahead

- Make a list of your financial goals by identifying specific priorities and timelines around your future plans.

- Estimate the amount required to achieve each goal.

- In the event that money gets tight, identify which goals are most important. 3) Step 3: Create a Saving Plan

- Establish definite goals for savings and determine the amount you wish to set aside regularly to meet these goals.

- Decide the most effective ways for accumulating regular savings. Consider the following factors: safety, yield, taxes, inflation, convenience and liquidity.

Table 9 is an example of what a savings plan might look like.

This table is an example of what a savings plan might look like. First, list your future goals along with their estimated financial goal and time horizon. If your financial goals are long-term, the savings plan should take into account an estimated rate of return or growth rate (i.e., compound interest, investment appreciation, etc.). The rate of return will vary depending on the length, type, and riskiness of the investment. The interest rates in this example are for illustrative purposes only and don’t necessarily reflect current interest rates. Students will need to estimate interest rates based on the types of savings instruments they use and current market factors.

Finally, use the time horizon and estimated rate of return to calculate the required monthly savings. There are many calculators on the Web that can help estimate a required monthly savings based on an interest rate and number of payments.

Take the most concerned priority listed in a survey conducted by Ralph A. and Thomas S. in 1991 "Planning for retirement" as an example, here below are some tips for saving for retirement:

- Stick with employers that match a higher percentage of the employee's contribution. In current social security saving plans, the maximum matching contribution rate can be 2 or 3 times of every RMB the employee invests. A college graduate will be wise enough to contribute the maximum amount possible to take the most advantage out of the free money offered by the employers. Actually college graduates are saving money by paying taxes on the contributions rather than withdrawals because they are in lower tax brackets now than they will be in years of retirement. Most importantly, you are assured to get a large dividend, at least 2 times the contribution at age of retirement since this is an insurance policy enforced by the credit of the government.

- Most jobs supply a minimal policy covering life and health insurance. Since medical treatment can be expensive, graduates can consider a catastrophic plan paired with a health savings account. The savings account lets you bank money tax-free to pay for smaller medical needs and cover big-ticket premiums. Graduates are charged with a lower health insurance fee because they're usually in good health conditions. This economical tax-free health fund will save you much from future medical care costs.

- Smart money back gold. This is a savings plan with coverage of life and cash inflows at regular intervals. For example, some insurance companies assure an extra $10 \%$ survival benefit to be paid till maturity on a 25-year basis, a yield higher than the demand deposit rate while the assured amount will be payable in event of death, disability and illnesses. Graduates can get access to adorable paybacks, life insurance and tax reduction by participating in this savings plan.

- In addition to deposit money in banks, graduates can deposit money in E-finance products like Yu Ebao which offers a yield higher than the demand deposit rate and withdrawals at will. Graduates can also save money by enjoying money transfer discounts and payment discounts with joint stores of these E-finance corporations.

\section{4) Step 4: Pay Your Self First}

Place the savings allocation in the budget and pay yourself first, not after other expenses have been met. Some savers find it helpful to have a portion of the check sent directly to a thrift institution or to have the employer make regular purchases of saving bonds on their behalf through payroll deduction. So the following is suggested: 
- When you create a budget, include your savings as a planned expense item.

- Treat your monthly savings like you would a car payment or a utility bill—except you're paying yourself.

- When you get your paycheck, immediately transfer your budgeted savings amount into a separate account, or see if your employer can deposit it directly into your savings account.

Here below are some ways to save money:

Saving include finding ways to save extra money and cutting down on unnecessary items.

On cutting down cost, college graduates can:

- Make do. Look for ways to avoid spending before rushing out to solve problems with an outlay of cash. It is less expensive to repair a broken screen than to replace it.

- Pack your own lunch, snacks and drinks. It's amazing how seemingly small amounts add up over time.

- Reduce spending in each category. Make it a game to try to cut expenses in each budget item by 5 or 10 percent.

- Eliminate unnecessary expenses. Special cable channels, magazine subscriptions, driving to work.

- Break costly habits - Smoking, gambling and eating out are huge money - grabbers. Stay at home and be creative.

- Save money and energy by running electricity - intensive appliances at night when the rates are lower.

- Delay purchases until you have shopped around for the best deal.

- Buy used instead of new. Try estate sales, yard sales and consignment shops.

- Learn to do more things yourself-e.g., home or auto repair, gardening, home remodeling.

- Use coupons and faithfully bank the savings.

Besides, we can also save using various saving instruments:

- Savings accounts

- Money market accounts

- Certificates of deposit (CDs) [9].

\subsection{Sixth Step: Investing the Money}

Smart saving can only prepare college graduates for emergency funds or other small funds, but investing can prepare them to be millionaires. But many college graduates are skeptical of getting involved in the financial markets because they either think that they lack the initial money to start investing, or they perceive investing as gambling which has high risk of losing money. Contrary to popular belief, a college graduate can master the art of investing without possessing a major in finance. Warren Buffett, the world's greatest investor once states, “Success in investing doesn't correlate with I.Q. once you're above the level of 25. Once you have ordinary intelligence, what you need is the temperament to control the urges that get other people into trouble in investing". All graduates can be smart investors one day if they bear the simple rules of smart investing in mind.

1) Some Common Investment Tools

- Bonds

- Stocks

- Mutual funds, Exchange-traded funds

- Real estate

- Commodities (gold, silver, etc.)

2) Some Tips about Choosing Investment Instruments for College Graduates

Bonds. Bonds are the safest securities to invest in. These fixed income securities are less risky because the investment return only changes when the contract terms are changed and the return is higher than deposit rates. The main purpose for a college graduate to take bonds as an investment is to balance out the risk of stocks in an investment portfolio which provide a higher return.

The stock market. Perhaps the most popular and profitable tool of investing are stocks. College graduates are able to tolerate the increased risk of stock investing because they have plenty of time to ride out the highs and lows of the stock market. For college graduates who want to be the stock market initiates, investing in mutual funds and hiring a financial advisor to manage their assets are good choices.

Mutual funds. Mutual funds are ideal for new investors because of their professional ability to invest in diversified portfolios as well as to provide the high returns. Mutual funds are essentially pools of money managed by individuals who invest in a wide variety of stocks and charge fund owners fees for these services. Mutual funds 
are the perfect investment for a recent college graduate because they require a smaller amount of initial investment than stocks and they often provide larger returns than individual investors.

3) Investment Tips for College Graduates

a) Step 1: Choose the Financial Instrument You Want to Invest

This depends on your return preference, risk preference and when you will need the money. Usually for long-term goal, such as a fund for a house, you may want to consider riskier investment products, knowing that if you stick to only the "savings" products or to less risky investment products, your money will grow too slowly - or, given inflation and taxes, you may lose the purchasing power of your money. And for short-term goal, five years or less, such as a car, you don't want to choose risky investments, because when it's time to sell, you may have to take a loss.

\section{b) Step 2: Watch Out For Diversification}

After choosing the instruments you want to invest, you need to watch out for diversification. Diversification is basically including a number of different types of investments in a portfolio in order to control risk and return. A common calculation for appropriate diversification in a portfolio subtracts an individual's age from 110 and the resulting number represents the percentage of stocks that should be held, with the remainder invested in bonds. Thus, someone who has just graduated from college in their early twenties should have about $90 \%$ of their money invested in stocks and only $10 \%$ in bonds.

\section{c) Step 3: Monitor the Investments}

Despite simply check an investment's performance regularly, you should compare that performance against an index of similar investments over the same period of time to see if you are getting the proper returns for the amount of risk that you are assuming. You should also compare the fees and commissions that you're paying to what other investment professionals charge.

While you should monitor performance regularly, you should pay close attention every time you send your money somewhere else to work. Make sure each trade was completed according to your instructions. Make sure the buying or selling price was what your broker quoted. And make sure the commissions or fees are what your broker said they would be.

\section{d) Step 4: Choose Someone to Help You}

Make sure the investment professional and her firms are registered.

Be wary of promises of quick profits, offers to share "inside information", and pressure to invest before you have an opportunity to investigate. These are all warning signs of fraud. Ask your investment professional for written materials and prospectuses, and read them before you invest [10].

\section{Conclusion}

This paper is written to introduce the basics of financial planning according to the priority concerns of college graduates. Financial security, the number one rated feature, is clearly an attainable goal for the individual if college graduates are wise in spending, saving, and investing which have long been overlooked by college graduates. By first educating themselves and then acting on that knowledge, today's college graduates have the potential to fulfill the great things that they desire because they have made wise financial decisions when starting out.

\section{References}

[1] Pope, R. and Howe, T.S. (1991) Characteristics and Needs of Students Interested in Financial Planning. Social Science Electronic Publishing. http://6aa7f5c4a9901a3e1a1682793cd11f5a6b732d29.gripelements.com/pdf/vol24.pdf

[2] Law, R.H. (2013) Importance of Personal Financial Planning for College Graduates (and Others). http://www.missourifamilies.org/features/financearticles/cfe82.htm

[3] Williams, A.E. (2008) The Essentials of Financial Planning for College Graduates. Senior Honors Theses, Paper 54. http://digitalcommons.liberty.edu/honors/54

[4] Oklahoma Department of Career and Technology Education Curriculum and Instructional Materials Center (2009) Life Skills: Financial Literacy Skills. http://www.okcareertech.org/educators/cimc/new-products/clusters/finance-cluster/pdf-files/financialliteracystudent.pdf

[5] FASFAA Graduate \& Professional Initiatives Committee (2007) The Road to Financial Planning. www.fpanet.org

[6] Academic Advising and Career Center of UTS (2010) Personal Financial Planning. 
[7] Tyson, E. (2010) Personal Finance for Dummies. Wiley Publishing, Inc. www.dummies.com/cheatsheet/personalfinance

[8] Securities and Exchange Board of India (2010) Lessons on Financial Planning for Young Investors.

[9] Waters, M. (2008) Financial Planning for Medical Graduates. www.myBPGinc.com

[10] U.S. SEC. (2005) Saving and Investing for Students. https://www.sec.gov

\section{Submit or recommend next manuscript to SCIRP and we will provide best service for you:}

Accepting pre-submission inquiries through Email, Facebook, LinkedIn, Twitter, etc.

A wide selection of journals (inclusive of 9 subjects, more than 200 journals)

Providing 24-hour high-quality service

User-friendly online submission system

Fair and swift peer-review system

Efficient typesetting and proofreading procedure

Display of the result of downloads and visits, as well as the number of cited articles

Maximum dissemination of your research work

Submit your manuscript at: http://papersubmission.scirp.org/ 